\title{
Sailing to Byzantinium - Icons, Apparatuses and The Mind-Body Problem
}

\author{
Rumo a Bizâncio - Ícones, Aparelhos e o Problema Mente-Corpo \\ Felipe Loureiro \\ Universidade Federal do Rio de Janeiro (UFRJ), Brasil \\ loureiro.fgsf@gmail.com
}

Navegando a Bizancio - Íconos, Aparatos y el Problema Mente-Cuerpo

\author{
DOI: https://doi.org/10.18472/cvt.21n1.2021.1924 \\ Redalyc: http://www.redalyc.org/articulo.oa? \\ id $=115466307010$
}

Recepción: 20 Marzo 2021

Aprobación: 12 Abril 2021

\begin{abstract}
:
Although our culture has apparently become increasingly immaterial in the last few decades, Victor Buchli argues that "the immaterial is always produced materially", and that "This apparent paradox, (...) is its generative power and what girds the productive dualisms of social life and sustains the metaphysics that secure our given ontologies" (Buchli, 2016, p. vii-viii). Likewise, Vilém Flusser argues that societies are shaped by the medium that dominates the organization of their cultures - the idea of History, for instance, would be derived from the linear structure of texts. Thus, a culture organized with and through electronic apparatuses - and the apparently immaterial images they produce - would then replicate their inner structure. However, since most of us do not understand how these apparatuses work, we usually settle with a simplified description: apparatuses are a combination of software and hardware, a new dualism that actualizes the ages-old mind/body dichotomy and plays an essential role in contemporary ontologies. Drawing from Buchli and Flusser, the paper argues that it is possible to trace enlightening parallels between the digital apparatuses that shape contemporary culture and the role of religious icons in late Antiquity, focusing on the ontological structures anchored in these apparently widely different media.
\end{abstract}

KEYWORDS: apparatuses, technical images, icons, immateriality.

\section{Resumo:}

Embora nossa cultura pareça estar em um processo de crescente desmaterialização, Victor Buchli argumenta que "o imaterial sempre é produzido materialmente", e que "Este aparente paradoxo (...) é seu poder gerador, que inclui os dualismos produtivos da vida social e sustenta a metafísica que salvaguarda nossas ontologias" (Buchli, 2016, p. vii-viii). Da mesma forma, Vilém Flusser diz que as sociedades são moldadas pelo meio que predomina na organização de suas culturas - a idéia de História, por exemplo, seria derivada da estrutura linear dos textos. Logo, uma cultura organizada com e por aparelhos eletrônicos - e as imagens aparentemente imateriais que eles produzem - deveria então reproduzir a estrutura interna destes aparatos. No entanto, poucos especialistas compreendem o funcionamento destes aparelhos, e o público em geral tende a se contentar com uma descrição simplificada: aparelhos são uma combinação de software e hardware, um novo dualismo que atualiza a dicotomia corpo/mente e desempenha um papel fundamental na construção de muitas ontologias contemporâneas. Partindo de Buchli e Flusser, o artigo propõe traçar um paralelo ente os aparelhos digitais que moldam a cultura contemporânea e o papel dos ícones religiosos no período Bizantino, focando nas estruturas ontológicas ancoradas nestes meios aparentemente tão distintos.

PaLaVras-chaVe: aparelhos, imagens técnicas, ícones, imaterialidade.

\section{Resumen:}

Aunque nuestra cultura parece estar en un proceso de creciente desmaterialización, Victor Buchli sostiene que "lo inmaterial siempre se produce materialmente", y que "esta aparente paradoja (...) es su poder generador, que incluye los dualismos productivos de la vida social y sustenta la metafísica que salvaguarda nuestras ontologías" (Buchli, 2016, p. vii-viii). Asimismo, Vilém Flusser dice que las sociedades están conformadas por el medio que predomina en la organización de sus culturas - la idea de Historia, por ejemplo, se derivaría de la estructura lineal de los textos. Por lo tanto, una cultura organizada con y por dispositivos electrónicos - y las imágenes aparentemente inmateriales que producen - debería reproducir la estructura interna de estos dispositivos. Sin embargo, pocos expertos entienden cómo funcionan estos dispositivos, y el público en general tiende a contentarse con una descripción simplificada: los dispositivos son una combinación de software y hardware, un nuevo dualismo que actualiza la dicotomía cuerpo/mente y juega un papel clave en la construcción de muchas ontologías contemporáneas. A partir de Buchli y Flusser, el artículo propone trazar un paralelo entre los dispositivos digitales que dan forma a la cultura contemporánea y el papel 
de los iconos religiosos en el período bizantino, centrándose en las estructuras ontológicas ancladas en estos medios aparentemente tan diferentes.

Palabras Clave: aparatos, imágenes técnicas, íconos, inmaterialidad.

\section{INTRODUCTION}

Fifty years ago, Norman Mailer covered the Apollo 11 mission for Life Magazine. For him, the sheer magnitude of the numerous technical challenges behind the moon landing "set electronic engineers and computer programs to dreaming of ways to attack the problems of society as well as they had attacked the problems of putting men on the moon" (Mailer, 1970). Back in 1969, this statement could be regarded as futuristic or even sensationalist, but the current debate regarding "smart cities" shows us that Mailer could be right: "many have become enamored with the same idea: What if the people who build circuits and social networks could build cities, too?” (Badger, 2018). The efficiency of the interconnected electronic apparatuses we use every day makes us dream about a time when our cities - or even our environment as a whole - will function with the same speed and reliability we find in our smartphones, tablets and notebooks.

According to Vilém Flusser, societies are shaped by the medium that dominates the organization of their cultures. The emergence of historical consciousness in the Western world, for instance, was a product of a culture based on linear writing. Thus, the culture shaped by linear writing is the only one that can really be called "historical" - the cultures that preceded it were prehistorical, and our current culture, shaped by the technical images produced by apparatuses like smartphones, computers and tablets, is posthistorical. This increasingly abstract culture seems to have engulfed almost all the media that made up the "body" of previous cultures, creating an apparently unprecedented way of being-in-the-world that combines different modes of presence.

However, as Rushkoff(2010) points out, our relationship with the apparatuses in which we rely to perform many of our daily activities has a peculiarity: most of us have no idea of how these apparatuses work.

When human beings acquired language, we learned not just how to listen but how to speak. When we gained literacy, we learned not just how to read but how to write. And as we move into an increasingly digital reality, we must learn not just how to use programs but how to make them. (...) Program, or be programmed. Choose the former, and you gain access to the control panel of civilization. Choose the latter, and it could be the last real choice you get to make (Rushkoff, 2010, p. 7).

The linear structure of texts is evident for every literate person in the world, and even the illiterate can still capture it in speech. Electronic apparatuses, however, are what Flusser calls "black boxes" - we know how to work with them, but their inner workings are completely opaque to most of us. Unable to understand the structure of these mysterious devices, we usually settle with a simplified, palatable description: apparatuses are a combination of software and hardware. This simplistic description may then be replicated in our attempt to understand other complex and opaque things such as cities, organizations, people and - why not? - ourselves. Stretching the software/hardware duality towards a new understanding of the mind/body problem, and acknowledging the speed in which hardware becomes obsolete, we tend to identify our Self or our conscience - with a software whose hardware seems to be as "upgradeable" or replaceable as an old mobile phone. This notion is evident in recent works of fiction - like the fifth season of the Black Mirror series - and in public debates regarding gender identity and transhumanism.

The opaqueness of the medium that sustains our culture may well be unprecedented, but the tension between the material and immaterial dimensions of culture is by no means a new issue. Victor Buchli argues that "the immaterial is always produced materially", and that "This apparent paradox, (...) is its generative power and what girds the productive dualisms of social life and sustains the metaphysics that secure our given ontologies" (Buchli, 2016, p. vii-viii). This notion drives Buchli's analysis of the history of the relationship between the material and immaterial aspects of culture and its impact on the ontological 
structures of past and present societies. This analysis begins in Byzantium, a culture dominated by the debates between iconoclasts and iconophiles over the complexities of a new form of image-making that would play a fundamental role in the shaping of Western culture from Late Antiquity to the Early Renaissance. The paper proposes that this apparently distant debate may illuminate our current discussions regarding the increasing immateriality of contemporary culture. Drawing from Buchli and Flusser, the paper argues that this apparent immateriality of contemporary culture is not exactly an unprecedented phenomenon, and that the religious icons produced in Late Antiquity had a role that can be related to the apparatuses that shape contemporary culture. Thus, it is argued that a philosophical approach to the study of heritage may point toward new ways of interpreting the current cultural environment.

\section{Apparatuses and Technical Images}

That is no country for old men. The young In one another's arms, birds in the trees, Those dying generations - at their song, The salmon-falls, the mackerel-crowded seas, Fish, flesh, or fowl, commend all summer long Whatever is begotten, born, and dies. Caught in that sensual music all neglect Monuments of unageing intellect.

Fuente: (Yeats, 1996, p. 193-194)

\subsection{The flusserian Model of Cultural History}

In Ins Universum der technischen Bilder, Vilém Flusser proposes a model of cultural history consisting of five rungs, each one symbolizing an era in which a specific medium prevailed in "the task of transmitting information crucial to society and to individuals" (Flusser, 2011). At the first rung, human beings were immersed in the Lebenswelt and could only express themselves through actions. Later, the creation of objects allowed them to extend and perpetuate these actions, leaving imprints and registers that could outlive them. This, according to Flusser, corresponds to the creation of culture. The third rung represents the world shaped by images that depicted and/or symbolized both actions and objects - Flusser calls these images "traditional images". Traditional images were overthrown around four thousand years ago, when linear texts began to explain images and gave rise to the historical consciousness. More recently, texts have been disassembled "into particles that must be gathered up", creating another level - "the level of calculation and computation, the level of technical images".

Flusser's model suggests a linear process of self-distancing - we are constantly stepping back from the direct experience of the world, going deeper into abstraction. However, when a new rung emerges, the previous ones are not forgotten. The movement from one rung to the next is a movement between different worlds shaped by different media. Flusser calls the fifth rung, shaped by the prevailing of technical images - images created by apparatuses such as cameras, television sets and computers, "a new, dimensionless level, one to be called, for lack of a more positive designation, 'posthistory". The term posthistory comes from the notion that History was created by the linear logic of writing, and that the prevalence of technical images - which are non-linear, but rather two-dimensional - marks the end of History.

Linear codes demand a synchronization of their diachronicity. They demand progressive reception. And the result is a new experience of time, that is, linear time, a stream of unstoppable progress, of dramatic unrepeatability, of framing: in short, history. With the invention of writing, history begins, not because writing keeps a firm hold on processes, but because it transforms scenes into processes: it generates historical consciousness (Flusser, 2002, p. 39). 
It may be difficult to know whether we are already in the fifth rung or climbing up towards it with a foot still strongly fixed on History. Northrop Frye's explanation for the shift from mythological to scientific discourse may clarify this situation:

\begin{abstract}
The cultural aura, or whatever it is, that insulates us from nature consists among other things of words, and the verbal part of it is what I call a mythology, or the total structure of human creation conveyed by words, with literature at its centre. (...) It is designed to draw a circumference around human society and reflect its concerns, not to look directly at the nature outside. When man finally gets around to doing that, he has to develop the special language of science, a language which becomes increasingly mathematical in idiom. Many things have to come together in a culture before science can begin, and when it does begin it does not descend from or grow out of mythology directly. Mythological statements about nature are merely grotesque or silly if they are thought of as pre-scientific explanations of it (Frye, 1980, p. 7).
\end{abstract}

Frye mentions the "verbal" part of culture, inside which the "textual" part - literature - is central. Therefore, mythological cultures were based on stories - and we could even say that these were very "imagetical" stories -, not exactly on texts, and much less on linear writing. When Frye mentions the scientific language, he does not seem to be talking about the language of modern science, but probably the language of Pythagoras, Archimedes and Euclid - who lived in societies built on myths, but on which the verbal part of culture was preponderant. This reminds us that the model proposed by Flusser is just a model, and that each rung does not represent the invention of a new medium, but the emergence of a new consciousness shaped by a new centrality.

\title{
2.2 Into the Universe of Technical Images
}

The Hyper Suprime Cam installed on the Subaru Telescope has recently allowed astronomers to discover Virgo I, a new ultra-faint galaxy that could not be seen through previous telescopes. An ultra-faint galaxy is obviously something that we understand as foreign, distant to the point of becoming abstract - and we are thus not estranged by the fact that we can only experience it through a sophisticated technical apparatus such as the Subaru Telescope. To say that we can only see something through an apparatus is the same as saying that we can only perceive and experience it as an image - which seems perfectly fine in the case of an ultrafaint galaxy. However, in our increasingly immaterial / digital culture, it is common to treat things that are very close to us as ultra-faint galaxies, only experiencing them as images.

In 2013, a composite image became popular throughout the Internet. It was a juxtaposition of two pictures taken at the same place, in similar events: the picture at the top showed Vatican square during the announcement of Pope Benedict XVI, in 2005; the picture at the bottom showed the same place during the announcement of Pope Francis, in 2013. In the first image, we can only see the back of dozens of heads as people are all turned to the same point, focusing on the historical event that is unfolding in front of them; in the second image, there is a sea of screens - smart phones, digital cameras, tablets - being held up in the air, trying to capture the event. Of course, many discussions unfolded on-line and offline, since the composition illustrated how so much had change in such a short period of time, and especially how people now seemed to feel the need to create personal records of events - or just to insert a technical medium between themselves and the world. 


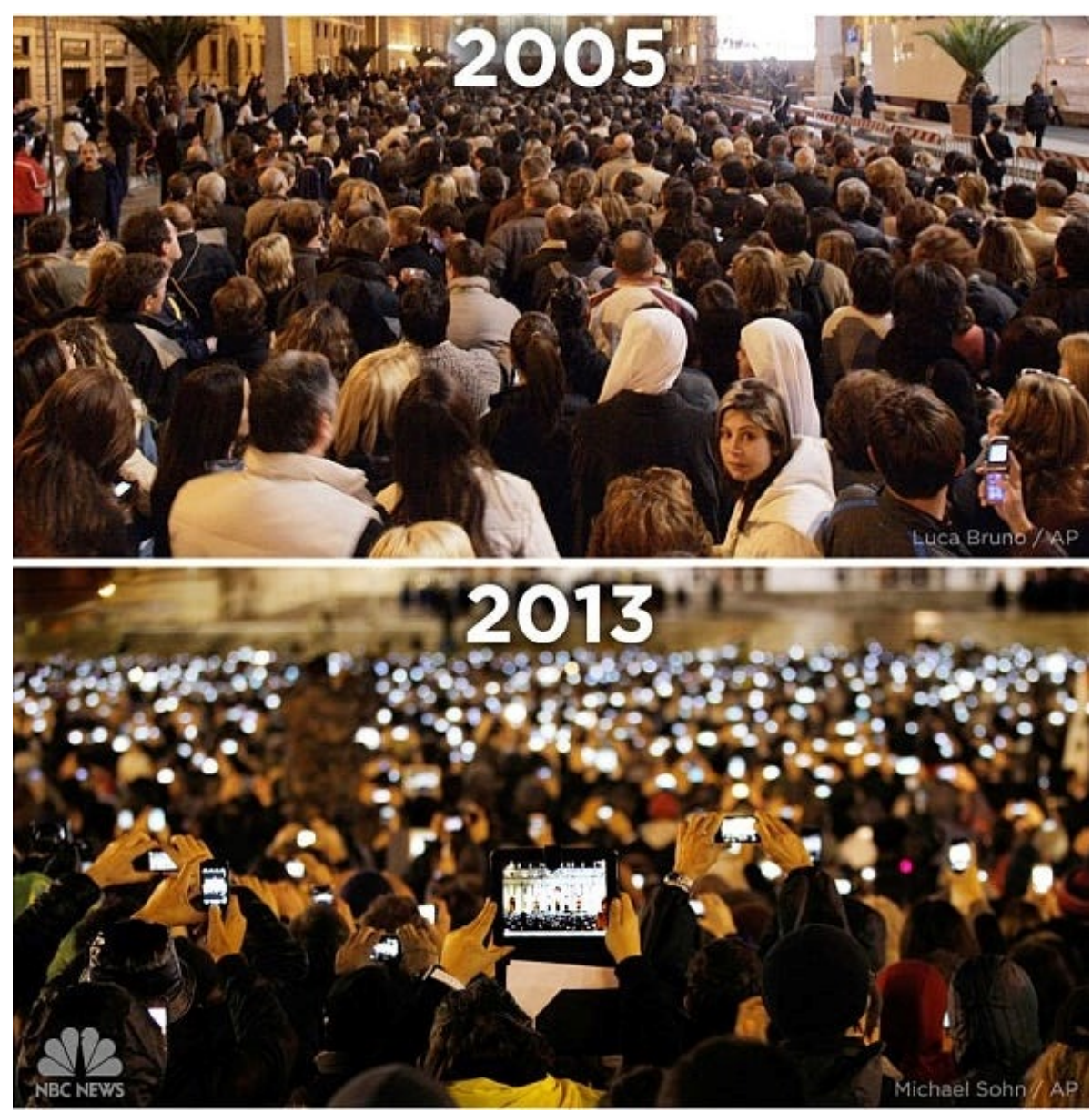

FIGURE 1

The collage that became viral - St. Peter's square in 2005 and 2013 (Taylor, 2013) Available at https://www.businessinsider.com/vatican-square-2005-and-2013-2013-3.

These examples have a twofold meaning: first, they exemplify our faith in digital apparatuses. We cannot see the ultra-faint galaxy with our eyes, but we believe that it does exist because the apparatus "tells us" that it does. Likewise, we believe the "story" told by the composition which illustrates, synthesises and confirms our feeling that the world is changing drastically at an increasingly disorienting pace. The fact that the picture at the top was actually taken during the funeral procession of Pope John Paul II has not gone viral, so the story lives on - both on-line and offline (Kolawole, 2013).

Second, in the case of Virgo I, the apparatus is a necessity; in the announcement of Pope Francis, it is a choice. The ultra-faint galaxy demands the mediation of an apparatus, so our experience of it does not really occur in space. Only the encounter with the apparatus - through which we see its image - happens in space. Thus, when people that are actually standing in Vatican square as Pope Francis is announced a few meters away feel the "need" to insert an apparatus between them and the event, they seem to be creating a different space inside the space of the square. This is a special kind of space, a relational space that the square, the historical stereotype of the urban public space, now seems to lack.

Heidegger used the term Ereignis - translated into English as appropriation or enowning - to describe the event of catching sight of something - "to see with the mind's eye, to see face-to-face" (Stambaug, in Heidegger, 1969, p. 14) -, and argues that enowning has a "technological 'veiling". In the case of Virgo I, the technological veiling is a precondition for enowning, and since "positionality is the "photographic negative' of enowning" (Mitchell, Raffoul in Heidegger, 2012, p. xii), it becomes clear that we are dealing with two positionalities that do not meet: the apparatus is positioned in order to catch a sight of the object, 
to appropriate - or apprehend - it; and we position ourselves not in relation to the apparatus, but to the images produced by the apparatus. Flusser uses the term "apparatus" to refer specifically to this kind of device that does not intend to transform the world, but to reveal it.

From one side there is the emergence of machines that aim to discover, and not to change the world, the so-called 'apparatuses'. It can be said that the telescope is good for seeing the mountains of the moon, as much as the mill is good for making flour, but it cannot be said that the mountains of the moon must be something else, as wheat must become flour. Apparatuses are good, but not good for something (Flusser, 2012)[1].

Apparatuses are objects that allow us to discover and experience other objects. In the case of an ultra-faint galaxy, they are the only way through which we can experience the object, but the constant use of apparatuses may well lead us to treat every object and every event as an ultra-faint galaxy. People holding up apparatuses high above their heads, trying to see Pope Francis through them instead of through their own eyes, seem to be trying to move back from the event, turning both the Pope and his announcement into an ultra-faint event. However, these examples also illustrate two different approaches to the creation of technical images.

Referring to categories of photographers defined by Andreas Müller-Pohle, Flusser argues that a documentarist "sits behind a wall with a hole in it and tries to record the world as much and as painstakingly as possible through that one hole", while a visualist "also sits behind that wall but tries to create a new hole to gain a new perspective on the world" (Flusser, 1982 apud Van Gelder \& Westgeest, 2011, p. 200). We are naturally prone to think of the scientists operating the Subaru telescope as documentarists, and the people recording Pope Francis as visualists - but it is hard not to see the revelation of never-before-seen confines of the universe as an attempt to "gain a new perspective on the world", and the recording of a historical event of worldwide appeal as an urge to capture the event as much as possible from one specific "hole". This shows us how it is difficult to pin out the difference between objectivity and subjectivity in what Flusser calls "the universe of technical images", especially because the spread of technical images and the centrality that they have gained in our culture has shaken the epistemological foundations that led us to conceive concepts such as object and subject.

\section{An Archaeology of the Immaterial}

An aged man is but a paltry thing, A tattered coat upon a stick, unless Soul clap its hands and sing, and louder sing For every tatter in its mortal dress, Nor is there singing school but studying Monuments of its own magnificence; And therefore I have sailed the seas and come To the holy city of Byzantium

Fuente: (Yeats, 1996, p. 193-194)

\subsection{The icon as "window"}

The immateriality of contemporary culture may seem unprecedented, but it is not as encompassing as common sense suggests. Victor Buchli argues that "the immaterial is by no means a unique quality of late capitalism or modernity but a thoroughly 'un-modern' aspect of human activity that has a long, if poorly understood, history" (Buchli, 2016, p. 1), and reminds us that "the immaterial is always produced materially" (Buchli, 2016, p. vii-viii). Of course, all the pictures, videos and words that pass by our screens are concretely stored in some distant mainframe, and are constantly bouncing between even more distant satellites, but this materiality does not seem to affect the way we experience these technical images. According to Buchli, the apparent paradox of the necessary materiality of the immaterial "is its generative power 
and what girds the productive dualisms of social life and sustains the metaphysics that secure our given ontologies" (Buchli, 2016, p. vii-viii).

In order to illustrate how the tension between the material and the immaterial is not a contemporary or even modern issue, Buchli discusses the role played by religious icons in Byzantine culture, focusing on the debates between iconoclasts - those who condemned the production of religious images, frequently identifying it with idolatry -and iconophiles - those who argued that these images were capable of communicating some transcendental meaning - that marked the eighth and ninth centuries. These controversies were "concerned with the question of how to presence the divine" - a fundamental ontological question at the time -, "producing the immaterial and the material means to do so" (Buchli, 2016, p. 52).

First of all, it is important to underline that, in Late Antiquity, paintings and works of art in general were conceived and perceived in ways that are quite different from modern and contemporary notions. In his 1919 essay "Reverse Perspective", Pavel Florensky confronts the centrality of representation - especially representations based on linear perspective - in the historical accounts and interpretations of Western art with an analysis of the religious icons of the Russian orthodox tradition, which reverberates the byzantine tradition studied by Buchli. Florensky argues that, until the Renaissance, linear perspective was only used in the "applied arts" that aimed at the creation of "illusions", especially in the theatre. In such cases painting was undermined, since it was subordinated to another art - a painting used as scenery only existed to serve the theatre, having no life of its own. In fact, even a free-standing, "independent" figurative painting that tried to replicate nature as it appears to be would already be a minor work - it would not be "pure" painting. The task of painting, Florensky argues, "is not to duplicate reality, but to give the most profound penetration of its architectonics, of its material, of its meaning", while "theatre decoration wants as much as possible to replace reality with its outward appearance" (Florensky, 2003, p. 209). For him, "pure painting is, or at least wants to be, above all true to life, not a substitute for life but merely the symbolic signifier of its deepest reality" (Florensky, 2003, p. 209-210). Painting has its own ways of communicating through symbols, not by imitating what the eye sees.

Likewise, Buchli relies on Barber (2002) and Frank (2000) to state that the icon was an image made to be looked "through", and not "at":

the 'icon' was a devotional image that served as an intermediary between the viewer and the person represented... the sacred portrait is best understood as a transparent window that the viewer looks through (to the 'prototype', the actual person represented) rather than at: the gaze does not stop at the surface of the panel, but goes to the prototype (Brubaker, cited in Barber, 2002, p. 29).

Barber argues that an icon is, therefore, the depiction of a prototype, but that it also functions as a relic, "being both original and a copy - a copy in the sense that it is a copy of the original prototypical image, and a relic in the 'haptic' sense by which it has had 'contact' with the prototype" (Buchli, 2016, p. 57). The icon is, therefore, a special kind of painting, and its composition follows a prototype that is not only visual. According to Florensky, when a painting tries to replicate the outward appearance of reality, "The aesthetics of this outward appearance lie in the inner connectedness of its elements", while the icon is "the symbolic signifying of the prototype via the image, realised by means of artistic technique" (Florensky, 2003, p. 209).

Although the icon is material, its surface provides a "site for exchange" in which the image mediates a contact with the divine. These conclusions presented by Brubaker and Barber were drawn from arguments made by iconophiles between the seventh and eighth centuries, but at the time these arguments found resistance among iconoclasts. Apart from the theological and political issues that divided these groups, one of the key issues in the debates between those who condemned the production of icons and those who argued in their defence was rather practical, or even technical: to which extent could a material medium be capable of making present the divine? Some iconoclasts relied on the gospels to argue that bread and wine were the only material media that could act as both depiction (or sign) and relic. However, iconophiles such as Nikephoros argued that "Making the absent present by manifesting the similarity and memory of the shape 
[the icon] maintains [with its archetype] an uninterrupted relation throughout its existence' (Nikephoros cited in Barber 2002, p. 119).

The focus on the "shape" of the icon - that, is, on the composition of the image depicted in its surface reinforces the material dimension of the archetype: if the shape of the icon must follow specific compositional rules in order to make present the prototype, then it would be reasonable to assume that these rules have somehow emanated from the prototype itself, or at least from its "realm". Therefore, the material medium of the icon - wood, paint, etc. - may be, by itself, unable to "touch" the divine, but the act of covering the surface of this medium with an image composed according to divine rules would turn the composite object - medium + media - into a transparent window[2] that offers a view of the prototype. It becomes necessary, then, to assert the divine origin of the "shape", which necessarily means to recognize that the work of the artist is limited by these divine rules - otherwise, the result will be just a depiction, never a relic. A similar argument is made by Floriensky regarding the Russian tradition - the painter of icons does not create the painting, but reveals it (Uspienski, 1976, p. 16 in Floriênski, 2012, p. 25). This revelation is achieved by following compositional rules that emanated from the prototype - the rules for the creation of an icon came from the realm inhabited by the prototype, whose presence in the material realm was made present by the icon. However, the artist must not try to copy the prototype, focusing "in the inner connectedness of its elements" - if he does that, he will be replacing the prototype with its outward appearance. Therefore, each icon is unique, even though its shape has to follow a set of compositional rules.
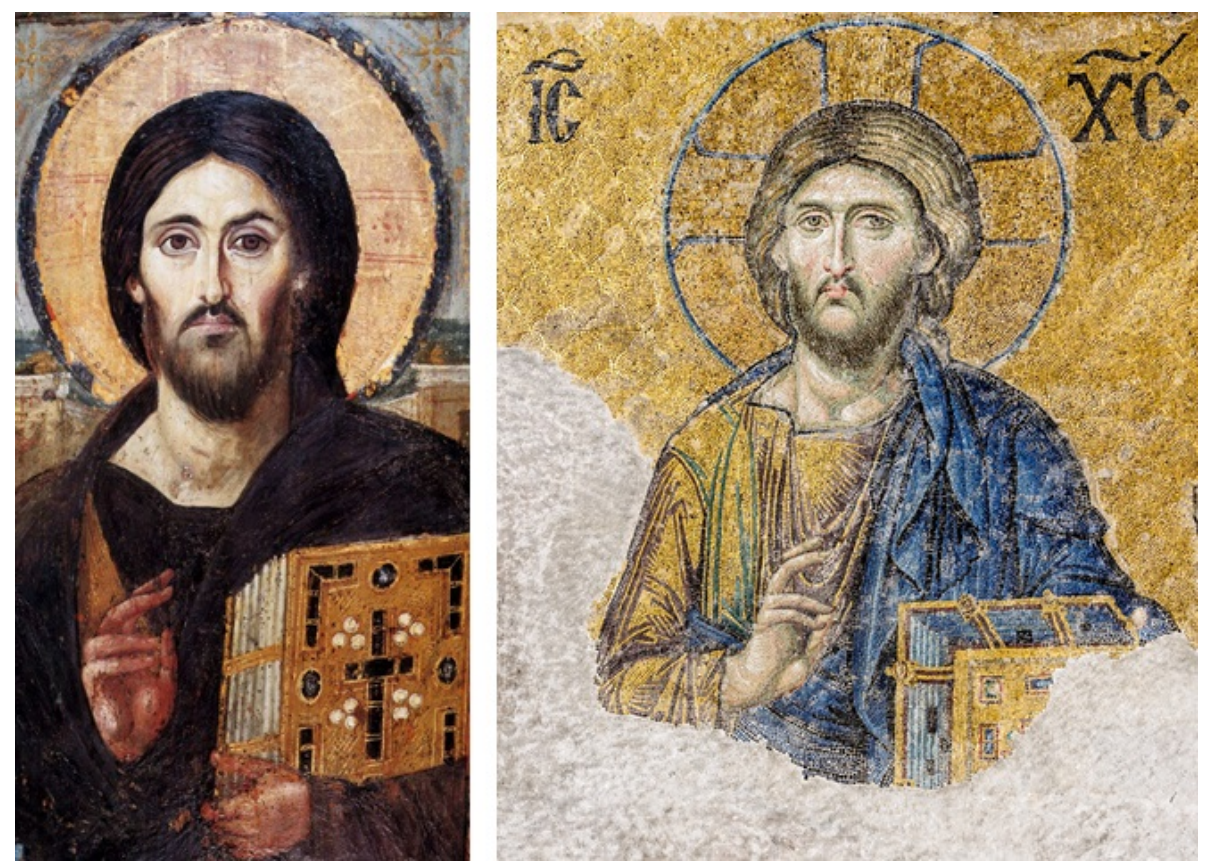

\section{FIGURE 2}

Right: Christ Pantocrator, 12th century (estimated), Hagia Sophia, Istanbul, Turkey Though six centuries apart, both icons depict the same prototype - the same elements are depicted in very similar positions and with the same visual hierarchy - with slight variations, especially in the facial expression of Christ.

Left: Icon of Christ Pantocrator, 6th century, Saint Catherine's Monastery, Mount Sinai, Egypt. Available at https:// commons.wikimedia.org/wiki/File:Spas_vsederzhitel_sinay.jpg Right: Christ Pantocrator, 12th century (estimated), Hagia Sophia,

Istanbul, Turkey. Available at https://commons.wikimedia.org/wiki/File:Christ_Pantocrator_Deesis_mosaic_Hagia_Sophia.jpg.

(Error 3: El enlace externo https://commons.wikimedia.org/wiki/File:Spas_vsederzhitel_sinay.jpg debe ser una

URL) (Error 4: La URL https://commons.wikimedia.org/wiki/File:Spas_vsederzhitel_sinay.jpg no esta bien escrita)

This understanding of the nature and role of icons in byzantine culture leads to two conclusions that will be developed in the next section: first of all, the icon was essentially a "site for exchange", a window through which mortals could have a glimpse of a higher reality[3]; it was, therefore, a relational object that depended on "the phenomenon of the co-presence of viewer, icon and divine prototype" (Buchli, 2016, p. 4). Secondly, 
since the production of icons had to follow specific rules that were believed to have a divine - or at least immaterial - origin, and since the artist was seen more as a "developer"[4] than a creator, icons can also be understood as proto technical images - images produced "automatically" by "programmed apparatuses

\subsection{The icon as "relational device" and "proto technical image"}

According to Flusser's model of cultural history, all images produced by human hands, without the use or mediation of apparatuses - from telescopes to smartphones -, are understood as traditional images[5]. Therefore, there would be no substantial difference between religious icons and the figurative/ representational paintings derided by Florensky. However, the relationship between the icon and the prototype suggests that these kinds of images may be too different to share the same category.

At this point, we should remember that one of the main arguments made by iconoclasts was that icons were in fact idols - images that could be worshiped by themselves, replacing the prototypes they were supposed to make present. However, as Buchli argues, "when an idol is destroyed then the divinity that inheres within the idol is destroyed along with it", while "The icon distributes presence rather than being localized; it is distributed because it refers to an immaterial prototype" (Buchli, 2016, p. 154). Therefore, the destruction of an icon does not damage the prototype - it is only the destruction of one among many possible paths towards the prototype. Thus, "Within the nexus of propinquity which constitutes the icon, the material artefact as thing is relational - it is a conduit" (Buchli, 2016, p. 154). In a way, the production of different icons from the same prototype protects it from destruction - only the prototype is irreplaceable.

According to Buchli, "Our notions of heritage and conservation as concerns museum artefacts is characterized by a similar understanding of visual and physical co-presence that one might attribute to an idol" (Buchli, 2016, p. 155). Most of our conservation efforts (still) focus on "unique", "authentic" objects that are deemed irreplaceable. However, the increasing dematerialization of our experience of culture may point towards a shift that would bring us closer to the logics of icons. Conventional works of art "do not work within the material register of the icon, whereas the 3-D printed artefact does, since the immaterial prototype, the stl file itself, is never harmed when the artefact is destroyed: it can be printed again indefinitely" (Buchli, 2016, p. 155-156).

It would be reasonable to argue that this approximation to the relationship between icon and prototype is already present in industrial design, and many mass-produced objects are displayed in museums all over the world. In this case there is no .stl file, but there are blueprints, construction drawings, specifications, etc. The main difference between a conventional industrial object and a 3-D printed artefact is the fact that the processes that produce the first are usually transparent and mechanical, whereas the latter seems to be produced "automatically" - almost magically - by a black box. Of course, the printing process of some 3-D printers may be as transparent as most conventional machines, and we should also consider that many - if not most - machines operating today already have embedded computers of some sort - in a way, they are all apparatuses with varying degrees of opacity. However, the 3-D printer is still understood as a special kind of machine because of its interface - there is a huge difference between managing a production line with a number of specialized apparatuses and just clicking on the "print" or "build" icon. Exactly because it presents a new way to produce materiality, the 3-D printer symbolizes the dematerialization of our culture - "Objects are produced from binary code like current digital music. (...) The object as a stable entity does not really exist; all that is stable is the binary code" (Buchli, 2016, p. 36). How is this different from an automated injection moulding machine working non-stop in a factory? The 3-D printer can be yours; you can keep it in your desk and click on the "build" button. The appeal of the 3-D printer is also relational - it relies on the co-presence of user, printer and code.

The experience of the icon presupposed that the viewer would see 'past' the icon to establish a relation with the prototype. Buchli argues that "such a form of seeing is penetrative" (Buchli, 2016, p. 156), and should be 
understood in the context of a "relation of sight to touch that derives from an Aristotelian understanding of haptic visuality" (Buchli, 2016, p. 4), something quite different from our current understanding of vision. Byzantine icons were therefore conceived and experienced in a different "sensorium", and aimed at transforming this sensorium, echoing Flusser's notion that a cultural medium may shape a whole new ontology - "The presencing technologies of the icon required a new way of cognizing presence and the theology of the era served to reconstitute this new form of perception and vision" (Buchli, 2016, p. 170). Since God made himself present in this world, a reappraisal of presence was not only necessary, but urgent "The figure of Christ suggested a new understanding of the material in the face of the Old Testament, which permits the use of images as material manifestations of the divine without being idolatrous" (Buchli, 2016, p. 6-7).

The sensorium shaped by the new form of presence introduced by religious icons was fundamental for the establishment and dissemination of Christian culture in Late Antiquity. Our current sensorium, however, is much closer to the overall structure established after the Renaissance, a new conception of the senses that "privileged a disembodied form of vision over other senses with the result that other sensually based forms of knowledge derived from touch and hearing are diminished in significance" (Buchli, 2016, p. 5). A disembodied vision can no longer (literally) touch the divine, penetrating an image in order to look past it. A picture is seen as a two-dimensional composition that can only be looked at, and artists become increasingly interested in exploring ways in which to break the limits of the picture, trying to represent threedimensional space. Painting becomes, then, closer to the sort of illusion or deception that Florensky believed to be "impure". It is the same disembodied vision, however, that will allow the emergence of the scientific method - the idea that one can observe a phenomenon "from outside", without interfering in it. The eyes were understood as windows to the natural world, windows that could eventually provide glimpses of the prototypes (laws) that lie behind Nature. The interest in the study of vision - from Berkeley to Goethe seems like an urge to confirm the unbiased character of vision, a notion that will eventually lead towards materialistic worldviews - only that which can be seen really exists.

While covering the Apollo 11 mission for Time Magazine, Norman Mailer wrote that "if the great brain of NASA were attached to any particular sense, it was the eye. The eye was the collector of incontrovertible facts" (Mailer, 1970). This new sensorium is centred on what Pallasmaa (drawing from Heidegger) calls "the nihilistic eye", a "hegemonic eye" that "seeks domination over all fields of cultural production" (Pallasmaa, p. 22). This nihilism emerged because sight is the most far-reaching of our senses - we can see stars many light years away -, and the most likely to become disembodied - "It is clear that only the distancing and detaching sense of vision is capable of a nihilistic attitude; it is impossible to think of a nillilistic sense of touch, for instance, because of the unavoidable nearness, intimacy, veracity and identification that the sense of touch carries" (Pallasmaa, p. 22). This detachment created the illusion of objectivity - or at least the possibility to deny subjectivity -, which was then transferred to apparatuses such as telescopes, microscopes, cameras, etc. - unsurprisingly, apparatuses that extended the already far-reaching sense of sight.

According to Flusser, "From the standpoint of so-called common sense, technical images are objective depictions of things out in the world" (Flusser, 2011, p. 49) - we trust photographs, videos and satellite images because these images seem to have been generated automatically though and automated, unbiased process. However, while Pallasmaa criticizes the illusory objectivity of most modern and contemporary theories and ways of producing of architecture - and the detachment from the sensual experience of space that derives from it -, Buchli mentions a "tyranny of the subject" in anthropology, especially in the field of material culture studies. This apparent contradiction is rooted in a more fundamental concept that permeates the social sciences, the idea that "the material was what was inscribed or projected upon by the social and cultural - things were literally mere illustrations of the social" (Buchli, 2016, p. 7). This notion is of course diametrically opposed to the main proposition introduced by Flusser - the medium informs (gives shape to) the ontology, and not the other way around -, but it explains both the objectivity of architecture and the 
subjectivity of anthropology: man-made material artifacts - from knick-knacks to buildings - are understood as formal/concrete expressions of intellectual concepts; thus, those who create artifacts focus on the pursuit of objective concepts to express, and those who study artifacts try to decipher and reveal the concepts behind them.

According to Buchli, a recent "sensual turn" may be adjusting the focus of the field towards "a new awareness of an expanded sensorium implicated in various forms of human knowledge in which the material is intimately and sensuously embedded" (Buchli, 2016, p. 9). This would be a major transformation, since this turn "refutes the significance of the more abstract and less dimensioned and less material aspects of materiality such as the visual and textual; representing of course a challenge to the prevailing postRenaissance sensorium which privileged such visual forms of knowing” (Buchli, 2016, p. 9). It may seem strange to minimize the role of visual forms of knowing in the universe of technical images, but the term "image" may be misleading. Even though many technical images can be experienced as visual images photographs, videos, animations, etc. -, and despite the fact that photography was the model chosen by Flusser to explain the concept of apparatus, the technical image is not an essentially visual medium.

Following Flusser's concepts, a photograph developed from film is as much a technical image as a digital photograph. An analogical $35 \mathrm{~mm}$ camera is as much an apparatus as a camera attached to the Deep Space Climate Observatory satellite. If we compare the processes that create analog (or film) photography and digital photography, we may be led to believe that these are completely different - one is chemical and therefore physical, material, whereas the other is digital, immaterial. However, it can be argued that the immateriality of the digital photograph is of course illusory, and that the optical and chemical processes that create the film photograph are as programmed as the software working inside the digital camera. "The technical image is an image produced by apparatuses. As apparatuses themselves are the products of applied scientific texts, in the case of technical images one is dealing with the indirect products of scientific texts" (Flusser 2000, p. 14). There is no fundamental distinction, therefore, between the scientific (textual) knowledge behind film development and software programming. However, the apparent immateriality of software makes the digital process look even more automatic, reinforcing the apparent objectivity of its output. As digital apparatuses overcome and replace analogical apparatuses, this impression of automated objectivity spreads to almost all fields of human activity.

Recent technological innovations in fact equate such things as houses and designs as text - as digitized code. Steel is cut
directly within CAD (computer aided design), sign and signified are inseparable and effectively one, challenging what we
understand as text and what we might understand as the materiality of the house - not to mention what the implications are
for our sensorial terms of reference when it is hard to segregate 'drawing' from 'cutting" (...) 'Or, as the examples from 3-D
printing will suggest, word is literally 'thing' when it is code that is the only 'stable' entity, that is 'printed' to make an object
in 3-D printing" (...) "The relation between the material and the immaterial and the hierarchies of our post-Renaissance
sensoria privileging 'vision' (and I include text within the visual) need to be reconsidered, as has been so forcefully and
eloquently asserted by figures such as Classen and Howes (2006) (Buchli, 2016, p. 9-10).

Coming back to the reflection on byzantine icons, it would be fair to say that the artist worked inside a framework that can be related to a program - "According to this model, the artificer is a tool working in the service of a higher inspiration. The artisan is necessary to the transformation of mere matter into a sacred object, but the validation for this act rests not with the artist but elsewhere" (Barber, p. 114). This interpretation of the icon makes it similar to an apparatus - the image on its surface being a sort of proto technical image[6]. The same file - prototype - can be visualized simultaneously in thousands of screens. The file itself is never present, and the screens are conduits that distribute the presence of the prototype, a presence that can be experienced in the form of a picture. The artist acts like the internal process through which the apparatus generates the image - he is the developer, the software.

There is, however, a crucial difference. In the case of the apparatus/technical image composition, the prototype inhabits the same world or dimension as the conduits. The icon, on the other hand, distributes 
a presence that was understood as being beyond this world - the conduit is a channel to another realm of existence. If we try to dissect both composites and compare their elements, the prototype of an icon would be parallel to the code that makes up a technical image, while the shape of the icon relates to the visualization of the technical image on the screen of the apparatus. However, the prototype that guides the creation of icons is believed to have a divine origin, and its goal is not only to give instructions on how to make visible a specific image, but to create a window through which a divine presence can be experienced. Thus, the technical image is an end in itself, whereas the shape of the icon aims to create a connection with another existential dimension.

Another crucial difference between icons and technical images lies on the fact that, while millions of smartphones will necessarily interpret the same code in the same way, making visible the same technical image, the same cannot be said if we consider two artists painting from the same prototype. Even though both artists are bounded by the same compositional rules given by the divine code, they are still human beings creating traditional images, and this process can never be fully programmed.

This last claim may sound obvious, but it is surely less obvious to us than it would be to a byzantine artist. In his account of the Apollo 11 mission, Mailer - who had an engineering degree - wrote extensively on what he called "the psychology of machines". Mailer used this term when describing episodes in which machines did not function according to plan, and argued that

"technology is founded on the implicit belief that machines are not possessed of psychology; the rifle jammed because of a speck of dirt in the breech, the car engine was flooded by the nervous foot of the driver, and the record-changer, far from having a mind of its own, rather had its record-changing procedure altered by careless handling. For every malfunction there is a clear cause technology must argue, a nonpsychological cause: psychology assumes free will” (Mailer, 1970).

The machines that were going to put three American men on the moon had to be reliable, precise, infallible. Every malfunction needed a rational - and external - explanation. The men themselves had to be as reliable as the machines - which, at the time, was achieved through military training, technical education and physical preparation. Nowadays, however, the apparent immateriality of the software behind our sophisticated electronic apparatuses allows us to believe in the possibility of pursuing this infallibility not only as a metaphor or even a mimetic discipline, but as an actual symbiosis. Contemporary culture is filled with stories and images of uploaded and downloaded minds, reprogrammed memories, etc. Even though we may not yet have the technology required to turn fiction into reality, the intention to do so is already telling - we seem to be attracted to the (non)psychology of apparatuses.

\title{
4. Mind x Body / Software X Hardware
}

\author{
O sages standing in God's holy fire As in the gold mosaic of a wall, Come from the holy \\ fire, perne in a gyre, And be the singing-masters of my soul. Consume my heart away; \\ sick with desire And fastened to a dying animal It knows not what it is; and gather me \\ Into the artifice of eternity
}

Fuente: (Yeats, 1996, p. 193-194)

\subsection{The mind-body problem and popular fiction}

The so called "mind-body problem" is the focus of many current discussions on the fields of philosophy, neuroscience, psychology and neurophilosophy. Philosopher Tim Crane provides an overview of these discussions in his book "The Mechanical Mind", organizing the most influential theories in three groups: materialists or physicalists argue that "the mind is just the matter of the brain organised in a certain complex 
way"; dualists propose that "there are two main kinds of thing - the material and the mental"; and a considerably smaller group of idealists suggests that "everything is ultimately mental" (Crane, 2016). Crane himself argues for a mechanical view of the mind - "the mind is a part of nature, something which has a regular, law-governed causal structure" (Crane, 2016, p. 91) - which derives, of course, "from thinking of nature itself as a kind of mechanism" (Crane, 2016, p. 2).

To say that nature is (like) a mechanism does not necessarily imply a materialistic / physicalist view. Anthony Dardis argues that "The world does proceed according to the laws of physical nature. But parts of it also proceed according to the laws of mental nature", clarifying that "The laws of physical nature don't rule out laws of mental nature, so long as the two are coordinated in a certain way" (Dardis, 2008, p. x). It is possible to acknowledge that the physical and the mental are two distinct "dimensions", each one working in accordance with specific laws, while understanding that these two dimensions are inside the realm of the "mechanism of nature". While there are many competing currents in the academic debate regarding the mind-body problem, most of the proposed models seem to rely on this notion of an overarching "natural mechanism" that works through and with universal laws.

It would be fair to say, however, that this apparent consensus may not extend to the general public. Barbara Hannan opens her introduction to the subject of the mind-body problem with a critique of "a certain widespread and almost certainly mistaken view of the nature of the mind: substance dualism" (Hannan, 2019 , p. 2). Substance dualism is the idea that each human being is composed of two substances, a physical body and a mind or soul. According to Hannan, "We live in a time when two views of the nature of persons, fundamentally incompatible with each other, are both widely accepted (often by the same individuals, who somehow remain blissfully unaware of the inconsistencies within their own thoughts). I mean the view of the nature of persons taken by physical science and a more ancient view of the nature of persons associated with many traditional religions" (Hannan, 2019, p. 2).

Contemporary popular culture provides many examples that seem to indicate that we may be engaged in a new kind of substance dualism - the mind-body problem may be understood as akin to the softwarehardware dichotomy. Fictional works such as many episodes in the Black Mirror series suggest that the mind is like a software that can be transferred between different hardware - "individuals' minds are extracted into vessels and settings constructed outside of the bodies in which they organically developed" (Muller, 2019, p. 96). In the last few decades, dystopian narratives that built on the nearly-apocalyptical consequences of an apparently inevitable clash between human beings and machines - such as the The Terminator film franchise - seem to have given way to stories in which the former belligerents become allies, or even indistinguishable entities. According to Muller, in the Black Mirror series "AI appears not in the guise of impersonal, Skynetlike circuitry with interests of its own and in opposition to those of humanity, but instead in the form of consciousness exported from an extant human being" (Muller, 2019, p. 96). Human x machine is replaced by human + machine, and the focus is adjusted toward a reflection on the nature of human beings, the identity between mind and body and the possibility of denying death not through the enduring of an immortal soul, but by transferring the mind/consciousness to another piece of hardware.

These discussions were of course not absent in earlier works. In films such as Blade Runner and A.I. Artificial Intelligence, these questions were already central - what is the difference between a human being and a machine to which we can relate as if it was a human being? Muller underlies that "There are high stakes in answering the question of exactly what distinguishes person from thing, since we traditionally view interactions between person and person or person and thing as warranting different kinds of ethical postures", and that "the treatment in Black Mirror of the 'cookie', the reproduction of a particular person's consciousness, affords insight into just how precisely the ways we treat AI could mirror the ways we have already treated real human beings." (Muller, 2019, p. 96).

The ethical dimensions of such discussions are of course highly relevant and were discussed in further detail in previous texts[7]. In this paper, however, I would like to underline the extent to which such stories seem 
to blend the traditional substance dualism condemned by Hannan with a computational view of the mind. According to Hannan,

\begin{abstract}
Once the basic claim of functionalism is accepted, that the essence of a given mental state is not its physical realization but its functional role, it becomes possible to draw an analogy between mental states and computational states, between minds and computer programs. Computers with different hardware can be in equivalent computational states, by virtue of running the same program and being at the same point in the program. Analogously, it can be conjectured that different systems (humans, silicon-based extraterrestrials, sophisticated robots) could all be in the same mental state, by virtue of being in the same functional state. The slogan 'the mind is to the brain as software is to hardware' is a pithy characterization of the computational theory of mind (Hannan, 2019, p. 36).
\end{abstract}

However, this analogy may be a self-fulfilling prophecy. If we understand mental states - we may call them feelings, thoughts, ideas, etc. - as functions of an overarching cognitive system that works according to preestablished, unavoidable laws, then we are already saying that the mind is like a computer - probably influenced by our close daily relation to these apparatuses. Anyway, examples from popular fiction seem to take only a few aspects of this analogy, especially the mobility of software and its apparent indestructibility. In Blade Runner [8], for instance, not all replicants "work" according to programmed mental states. The plot builds on the fact that these machines were so akin to human beings that a group of them - led by Roy Batty - rebelled against their predetermined "expiry date" and engaged into a quest to meet their creator - Dr. Tyrell - and confront him, what does happen in what is now known as "the prodigal son scene":

Tyrell: What seems to be the problem?

Roy: Death.

Tyrell: Well, I am afraid that is a little out of my jurisdiction, you -

Roy: I want more life... father.

(...)

Tyrell: The code sequence cannot be revised once it has been established.

(...)

Tyrell: You were made as well as we could make you.

Roy: But not to last (Fancher \& Peoples, 1982).

In this dialogue, Roy discovers that his expiration date cannot be changed - it is programmed into him and cannot be altered, not even by his maker. Thus, Roy is ultimately a machine whose program includes its own unavoidable, unstoppable destruction. However, Tyrell's assistant Rachael, which was at first introduced as a human, is revealed - but not to herself - to belong to a new generation of replicants created with embedded memories and who are not aware of their condition or of their expiration date. Therefore, the main question that lingers at the end of the film is basically "is Rachael human, even though we now that she is a machine?" Of course, one can argue that Roy's revolt against death is a proof that the "human program" was replicated correctly - not accepting your inevitable death may just be a mental state, a function of the human system. Thus, instead of thinking "is Rachael like us?" we can also think "are we like Rachael?" - as programmed as a computer, just unaware of it?

\title{
4.2 A relational approach: The world-brain problem
}

At this point, it would be fair to ask how all of this can be related to byzantine icons and/or to Flusser's concepts. Going back to Buchli, it can be argued that both a byzantine Pantocrator icon and a Hollywood film such as Blade Runner express "the productive dualisms of social life" that sustained the "given ontologies" of each period. If we accept the model of the computational mind, we must then accept that both the revolt against death and the painting of an icon are mental states that could also be "experienced" by a machine - be it the replicant Roy Batty or some sort of icon-painting apparatus. In fact, any human creation must 
be somehow already inscribed into the program of the human mind, which may have been called, in earlier times, as the realm of poiesis.

This sounds very materialistic, but the notion may not be that secular. The Christian notion of the Divine Logos presupposes that, before the beginning of time, Creation already existed as a possibility in God's "mind" - we can say that it was already part of its program. Of course, considering that God is omniscient and all-powerful, one can infer that everything must necessarily be included in his mind's program, and that the Divine Logos would then be the supreme program, the meta-program. In Hans Urs von Balthasar's reading of the theology of Gregory of Nyssa (von Balthasar, 1995), the act of Creation coincides with the creation of space, or of "a space" between God and something which is not Him - something we can call creation, spanning from the simplest mineral to the most complex of mammals. The act of creation is understood in relational rather than objective terms, something similar to the acknowledgement of the otherness in nonhuman subjects in Blade Runner and Black Mirror - Rachael was created by a man, while "real" human beings were created by God or nature; but from the viewpoint of the creature, what is the difference?

Georg Northoff argues that "Neuroscientists investigate the brain in empirical terms and search for neuronal mechanisms underlying mental features including consciousness, self, free will, and others", while "Philosophers, in contrast, associate mental features with the mind"[9], and that, in both cases, "any relation to the world is left out" (Northoff, 2018, p. xi). Most debates on the relation between the mind and the body seem to focus on the apparently internal interplay between these two entities - even for those who consider one to be the originator of the other -, mostly dismissing the relations between these entities and the "world". For Northoff, the mind-body problem is not the right problem to be tackled - "it would be better to raise the question of the existence and reality of mental features in terms of the brain's relation to the world, the world-brain relation, as I call it" (Northoff, 2018, p.vii).

The question is not whether the mind guides the body, or if it is part of the body or something detached from it - the main issue is to understand the relation between the mind/brain and the space/context in which it exists. This shift in perspective is deeper than it may seem, since it replaces a metaphysical problem with an ontological problem (Northoff, 2018, p.xiii)[10], focusing on how the brain's spontaneous activity and spatiotemporal structure are aligned with the world - and relying on empirical evidence which suggests "that such spatiotemporal alignment of brain to body and world is central for consciousness" (Northoff, 2018, p.xvi).

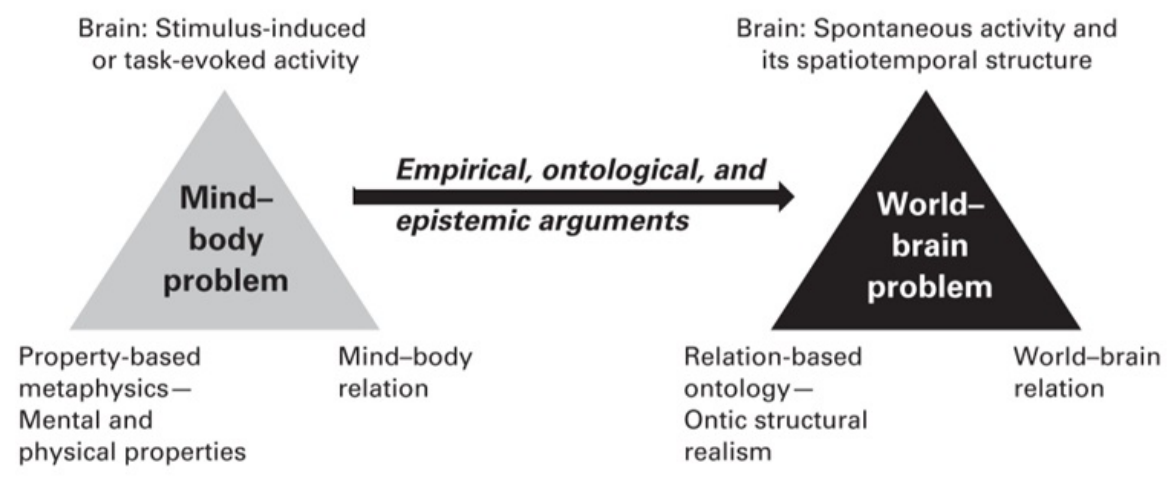

FIGURE 3

"From the mind-body problem to the world-brain problem"

(Northoff, 2018, p. xxiv)

If we shift the focus from the mind-body problem towards the world-brain relation, while also accepting the computational view of the mind, it becomes possible to include computers in the discussion. If Blade Runner's Rachael and A.I.'s David live in the same world as humans and can process the same mental states 
experienced by them, from the viewpoint of the world-brain relation there would be no difference between replicants, Mecha and human beings.

Discussing the ontological status of fictional characters may seem to be just an amusing exercise, but this exercise may prepare us to deal with similar questions that may soon challenge us. In 2004, Neil Harbisson, a visual artist and musician, attached an antenna to his skull in order to expand his senses. Harbisson was born colour-blind and developed an apparatus that would enable him to "hear colours" - the antenna is equipped with a webcam and attached to a small portable computer that translates colours into sound waves that can be heard through headphones (Stix, 2016). After months of adaptation, Harbisson was able to identify even infrareds and ultraviolets, which cannot be captured by human vision (Stix, 2016).

By combining his body with an apparatus, Harbisson changed his brain's relation to the world, adding unforeseen dimensions. His natural sensory apparatus was upgraded by a man-made apparatus that is seen - at least by Harbisson himself - as an extension rather than an accessory. It can surely be argued that, even though Harbisson is commonly referred to as "the first cyborg artist" (Jeffries, 2014), anyone carrying an artificial pacemaker - an apparatus available since the early 60's - would be as much of a cyborg as him. However, in the context of a culture shaped by technical images, the fact that Harbisson's antenna looks as part of his body and seems to expand the reach of both his body and his mind does help to blur the boundaries between the natural and the artificial. 


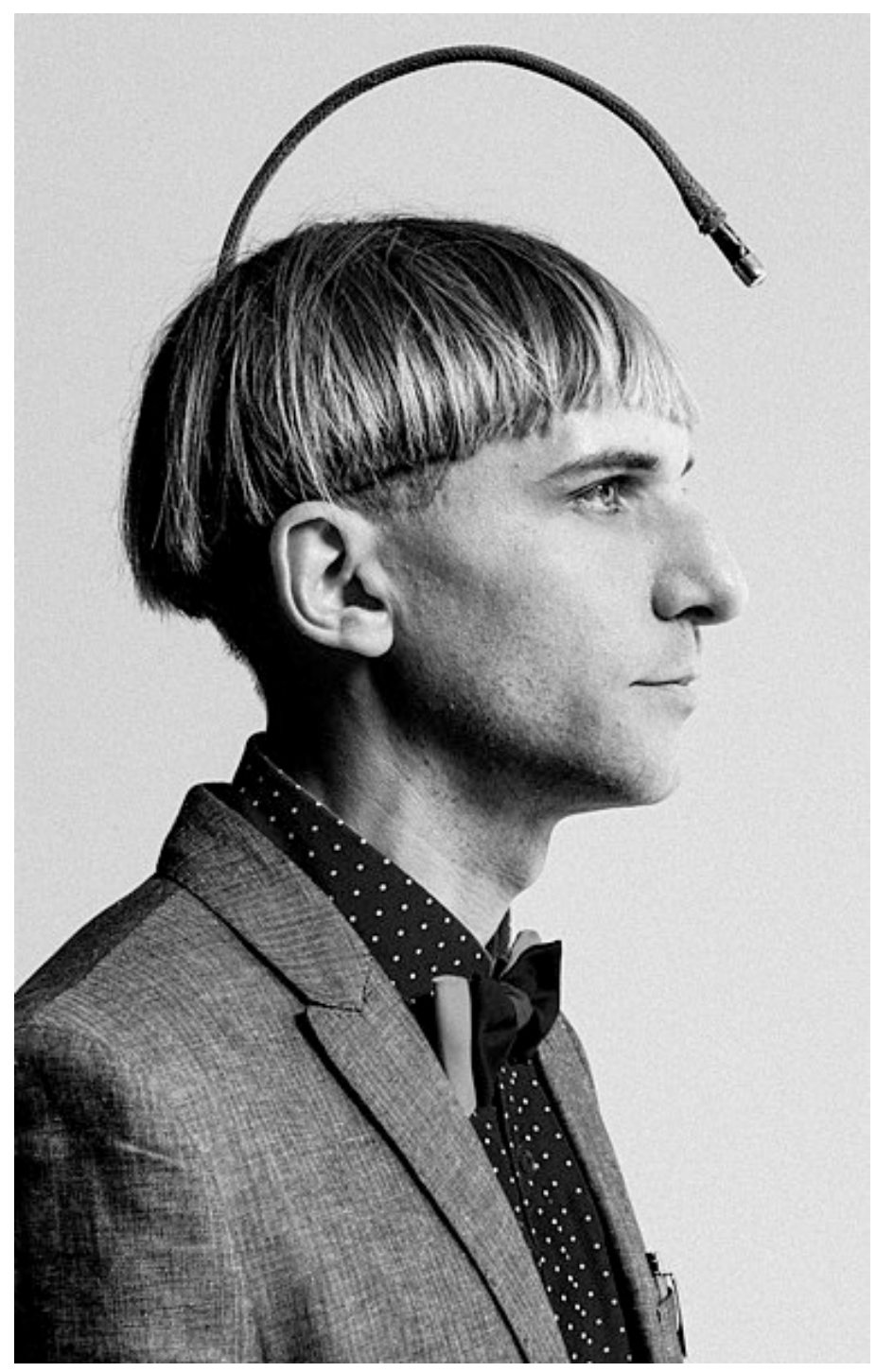

FIGURE 4

"Biohacker artist Neil Harbisson with his cyborg antenna implanted in his skull to extend his sense of color beyond human perception"

Photograph by Hector Adalid, available at https://commons.wikimedia.org/wiki/File:Biohacker_Neil_Harbisson.jpg

\section{Conclusion(s)}

Once out of nature I shall never take My bodily form from any natural thing, But such a form as Grecian goldsmiths make Of hammered gold and gold enamelling To keep a drowsy Emperor awake; Or set upon a golden bough to sing To lords and ladies of Byzantium Of what is past, or passing, or to come.

Fuente: (Yeats, 1996, p. 193-194)

In March 2021, Christie's promoted an online auction to sell its first all-digital artwork. "Everydays: The first 5.000 days" is a collage by digital artist Mike Winkelmann (a.k.a. Beeple), but the object of the auction was not a high-resolution print of the work, nor the "original" jpg file created by the artist. Bidders were interested in acquiring a NFT (non-fungible token) file, which is a certificate of authenticity for the jpg file. The link between the jpg file and the NFT certificate is protected by a blockchain, so it cannot be 
copied or replaced. The token is "non-fungible" because it is unique, unlike a cryptocurrency that emulates conventional currency - all one-dollar bills have the same value. A NFT is a unique certificate related to only one specific object - in this case, Beeple's collage, which only exists as a jpg image file. "The NFT file doesn't contain the digital piece of art (...). It's just a kind of contract, saying 'the owner of this NFT owns this other digital file,' often with a link to the art file itself" (Dean, 2021). Thus, the winning bid of over 69 million dollars did not purchase a print nor a jpg file, but "one-of-a-kind bits of code with a verifiable chain of title attached" (Dean, 2021).

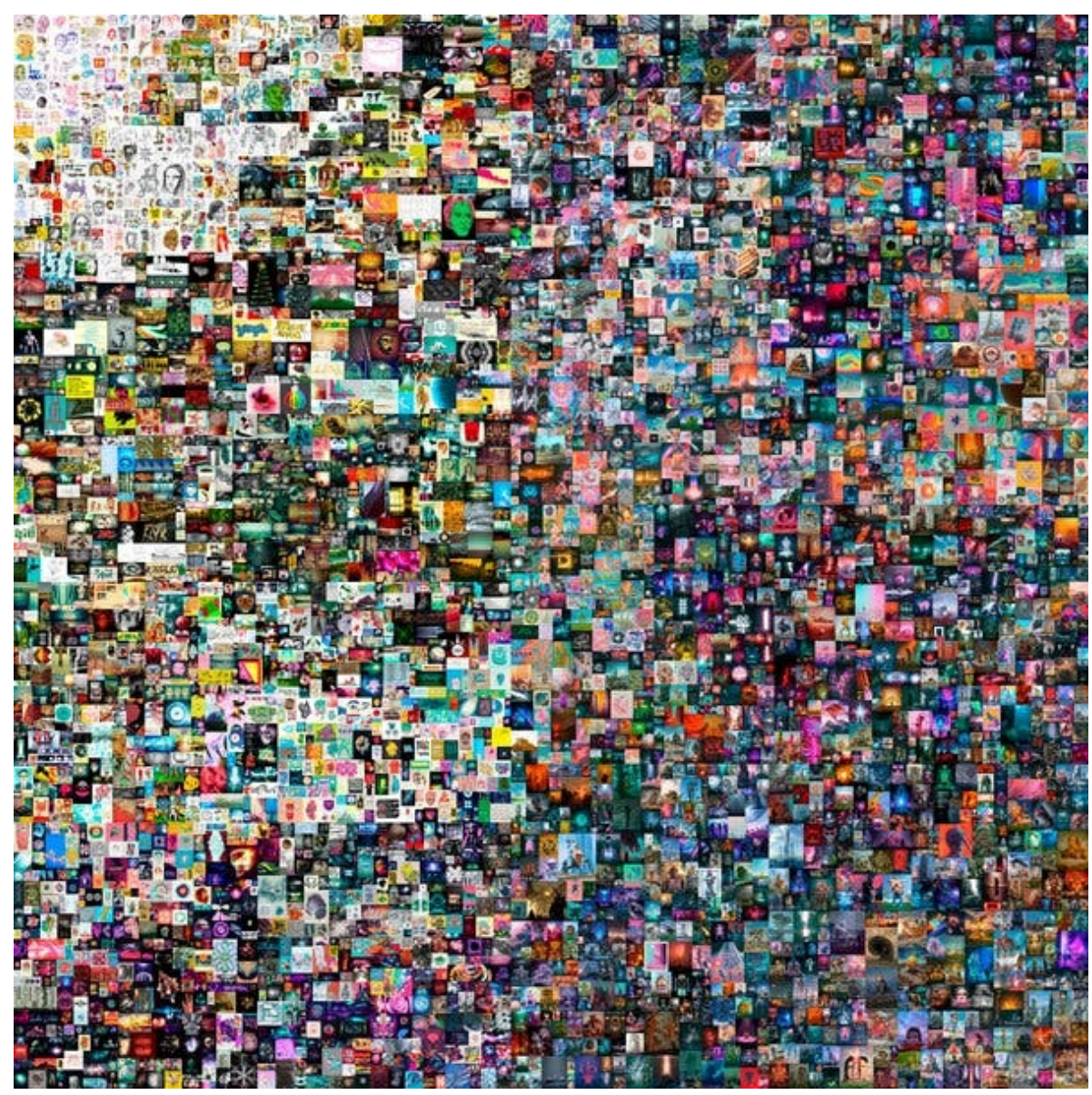

FIGURE 5

"Beeple (b. 1981), EVERYDAYS: THE FIRST 5000 DAYS, 2021. Non-fungible token (jpg). 21,069 x 21,069 pixels (319,168,313 bytes). Minted on 16 February 2021. Sold for $\$ 69,346,250$ in a single lot sale concurrently with First Open”.

Available at https://www.christies.com/features/Monumental-collage-by-Beeple-is-

first-purely-digital-artwork-NFT-to-come-to-auction-11510-7.aspx?sc_lang=en\&lid=1

In a way, since "All an NFT does is authenticate and record the provenance of the NFT itself" (Dean, 2021), it can be somehow related to "official" reproductions of photographs or engravings - signed or at least "permitted" by the artists -, something that can be traced back to the Renaissance[11]. However, in this case, the "original" jpg file is a collage of all the images the artist produced and posted on his Instagram account https://www.instagram.com/beeple_crap/ - between 2007 and 2021. Thus, the work itself is freely available on the internet, and all images can be copied, edited, shared, etc. From the standpoint of the relation with the work of art, the owner of this particular NFT does not seem to have any "advantages" - the collage is not hung or stored somewhere for exclusive personal enjoyment. Anyone who can access Instagram can have a very similar experience. Thus, the NFT seems to be an attempt to attach a sort of artificial uniqueness to a technical image, reacting against its reproducibility. 
However, the driving force behind this reaction may not be as philosophical as it may seem. The artificial scarcity created by NFTs is more relevant to the art market than to the experience of art. Beeple's NFT file made him "the third most-expensive living artist after Jeff Koons and David Hockney" (Crow, Ostroff, 2021). Curiously, while the market value of digital art approaches that of conventional, physical art, its materiality is already surprisingly bulkier. "Processing cryptocurrency transactions takes a massive amount of computing power, which has raised environmental concerns about the boom" (...) "On a larger scale, the computer networks that collectively make up the bitcoin and ethereum blockchains are estimated to use as much electricity as Argentina and Ecuador, respectively, each year" (Dean, 2021).

Through this example, we are once again reminded of the inescapable materiality of artifacts that we usually believe to be immaterial. What we see as dematerialization is just the replacement of one material form by another material form that is more distant from us. Our belief in the dematerialization of our culture comes from the perpetuation of a dualism that is a long-lasting "vestige of the Cartesian mind/body split" (Buchli, 2016, p. 146). This does not mean, of course, that we should ignore the radical changes brought by this new form of materiality. Technical images are so fundamentally different from the media that preceded them that we are still learning how to relate to them - but this has not stopped us from building a whole new world based on these mysterious artifacts.

It seems, therefore, that we are currently in need of a deeper ontological understanding of what does it mean to live in the universe of technical images, and I believe that this situation is very similar to the crisis faced by those involved in the iconoclastic controversy of the byzantine period. Early Christian thinkers and artists were puzzled not only by the problem of how to communicate the Christian message, but also by the event of incarnation itself, and they understood that it was necessary to develop a new sensorium in order to both understand and express this phenomenon (Frank 2000; Barber 2002, apud Buchli, 2019, p. 170). According to Buchli, "The presencing technologies of the icon required a new way of cognizing presence and the theology of the era served to reconstitute this new form of perception and vision" (Buchli, 2016, p. 170). Likewise, Flusser argues that "A true understanding of techno-images - and implicitly of all images - implies a criticism of their mimetic, representational side, a move from objectivity towards intersubjectivity, a focusing on the relationship between subject and object and a constant phenomenological effort at deciphering techno-images both within scientific and everyday contexts" (Guldin, 2009, p. 17).

Flusser coined the term "techno-imagination" to refer to this new attitude towards technical images and the world shaped by them, "suggesting that the way we look at the world is ultimately a question of intersubjective, that is, dialogic convention" (Guldin, 2009, p. 18). This relational approach echoes both the core of the iconoclastic controversy - the possibility of a direct encounter with the divine through/in the icon - and Northoff's answer to the mind-body problem - reframed as the brain-world relation. Therefore, the apparently distant world of traditional images can surely provide valuable insights to those who dwell in the universe of technical images. The objects being discussed may have changed, but the subject of the discussion is basically the same - and it will always remain the same. The illusions created by technical images may lead us to believe that our world is opaquer and more mysterious than ever, or, in contrast, that it will eventually be completely revealed - and controlled - by apparatuses. Anyway, in order to really understand our condition, we may need to overcome a worldview based on the material/immaterial duality, abandon any faith in the objectivity of technical images and articulate a new sensorium that may explore and expand the imaginative possibilities provided by apparatuses.

\section{REFERENCES}

Abreu, P. \& Costa, T. (2014, December 11-12). Vèronique, ou a redenção pelas imagens: Valor e significado das obras de arte figurativas na arquitectura de igrejas [Paper presentation]. Patrimonio Architettonico Religioso: Nuove funzioni e processi di trasformazione, Turin, Italy. 
Antonova, C. (2010). Space, Time, and Presence in the Icon: Seeing the World with the Eyes of God. Farnham, Surrey: Ashgate Publishing Limited.

Badger, E. (2018, March 4). “Tech Envisions the Ultimate Start-Up: An Entire City”. Retrieved from https://www. nytimes.com/2018/02/24/upshot/tech-envisions-the-ultimate-start-up-an-entire-city.html

Barber, C. (2002). Figure and Likeness: On the Limits of Representation in Byzantine Iconoclasm. Princeton University Press.

Brubaker, L. (1998). "Icons before Iconoclasm?" Settimane di studio del Centro italiano di studi sull'alto medioevo, 45: 1216.

Buchli, V. (2016). An Archaeology of the Immaterial. London: Routledge.

Buchli, V., Lucas, G. (2001). Archaeologies of the Contemporary Past. London: Routledge.

Crane, T. (2016). The Mechanical Mind: A Philosophical Introduction to Minds, Machines and Mental Representation. London: Routledge.

Crow, K., Ostroff, C. (2021, March 11). "Beeple NFT Fetches Record-Breaking \$69 Million in Christie’s Sale”. Retrieved from https://www.wsj.com/articles/beeple-nft-fetches-record-breaking-69-million-in-christies-sale11615477732

Dardis, A. (2008). Mental Causation: The Mind-Body Problem. New York: Columbia University Press.

Dean, S. (2021, March 11). “\$69 million for digital art? The NFT craze, explained”. Retrieved from https://www.lati mes.com/business/technology/story/2021-03-11/nft-explainer-crypto-trading-collectible

Fancher, H., Peoples, D. (Writers), \& Scott, R. (Director). (1982). Blade Runner. Hollywood, Hong Kong: The Ladd Company, Shaw Brothers and Blade Runner Partnership.

Florensky, P. (2003). Beyond Vision: Essays on the Perception of Art. London: Reaktion Books.

Flôrienski, P. (2012). A Perspectiva Inversa. São Paulo: Editora 34.

Flusser, V. (2000). Towards a Philosophy of Photography. London: Reaktion Books

Flusser, V. (2011). Into the Universe of Technical Images. Minneapolis: University of Minnesota Press.

Frank, G. (2000) The Memory of the Eyes: Pilgrims to Living Saints in Christian Late Antiquity. Berkeley: University of California Press.

Guldin, R. (2007). "Iconoclasm and Beyond: Vilém Flusser's Concept of Technoimagination". Studies in Communication Sciences, Volume 7, N. 2, p. 63-83.

Hannan, B. (2019). Subjectivty \& Reduction: An Introduction to the Mind-Body Problem. London: Routledge.

Jeffries, S. (2014, May 6). "Interview - Neil Harbisson: the world's first cyborg artist". Retrieved from https://www.t heguardian.com/artanddesign/2014/may/06/neil-harbisson-worlds-first-cyborg-artist

Kolawole, E. (2013, march 14). "About those 2005 and 2013 photos of the crowds in St. Peter's Square”. Retrieved from https://www.washingtonpost.com/blogs/innovations/post/about-those-2005-and-2013-photos-of-the-c rowds-in-st-peters-square/2013/03/14/aaf1067a-8cf9-11e2-9f54-f3fdd70acad2_blog.html?noredirect=on

Lings, M. (2006). Symbol and Archetype: A Study of the Meaning of Existence. Fons Vitae.

Loureiro, F. (2015). “The Image In Power: Vilém Flusser and the Craft of Architecture”. Architecture Philosophy, Volume 1, N. 2, pp. 214-23.

Loureiro, F., Bartholo, R., "Tropical and Eastern Paris: architecture, representation and tourism in Brazil and China”. Journal of Tourism and Cultural Change, v. 17, p. 1-13, 2019.

Loureiro, F., Bartholo, R., Mattos, F., Barcelos, F.T. "Visitar/Acolher: Arquitetura, Turismo e Encontros". REVISTA HOSPITALIDADE, v. 17, p. 95-108, 2020.

Loureiro, F., Bartholo, R., Mattos, F., Sanchez, E. “Da intangibilidade do tangível: por uma abordagem relacional do patrimônio”. PAPERS DO NAEA (UFPA), v. 29, p. 321-335, 2020.

Mailer, N. (1970). Of a Fire on The Moon. New York: Random House. 
Muller, Christine (2019). "We Have Only Ourselves to Fear: Reflections on AI Through the Black Mirror of "White Christmas"” in McSweeney, Terence; Joy, Stuart (Ed.). Through the Black Mirror: Deconstructing the Side Effects of The Digital Age. Cham: Palgrave Macmillan.

Pila, J., Torremans, P. (2019). European Intellectual Property Law. Oxford University Press.

Rushkoff, D. (2010). Program or Be programmed: Ten Commands for a Digital Age. New York: OR Books.

Stix, M. (2016, January 7). "World's first cyborg wants to hack your body". Retrieved from https://edition.cnn.com/ 2014/09/02/tech/innovation/cyborg-neil-harbisson-implant-antenna/index.html

Taylor, A. (2013, March 14). “There Was Something Different About The Vatican Crowd In 2005”. Retrieved from https://www.businessinsider.com/vatican-square-2005-and-2013-2013-3

Van Gelder, H., Westgeest, H. (2011). Photography Theory in Historical Perspective. Chichester: Wiley-Blackwell.

von Balthasar, H. U. (1995). Presence and Thought: Essay on the Religious Philosophy of Gregory of Nyssa. San Francisco: Ignatius Press

Yeats, W. B. (1996). The Collected Poems of William Butler Yeats. New York: Scribner.

\section{Notes}

[1] Original quote: "De um lado surgem máquinas que servem à descoberta, e não à modificação, do mundo, os ditos "aparelhos". Pode-se dizer que o telescópio é bom para ver as montanhas da Lua, tanto quanto o moinho é bom para fazer farinha, mas não se pode dizer que as montanhas da Lua devem ser outra coisa como o trigo deve ser farinha. Os aparelhos são bons, mas não são bons para algo" (Flusser, 2012) - translation by the author.

[2]For a broader discussion on the role of images and (literal) windows in the spatial experience of churches, see Abreu \& Costa (2014).

[3] Martin Lings interprets Islamic art in a similar way, arguing that Islamic tradition considers that “(...) the universe and its contents were created in order to make known the Creator" and that "(...) the means of making it known is to reflect it or shadow it; and a symbol is the reflection or shadow of a higher reality" (Lings, 2006).

[4]The term "developer" here relates to the process of developing photographic film.

[5]Many scholars criticize the fact that Flusser does not address the concept of traditional images very thoroughly. Hans Belting, for instance, underlines the imprecision with which Flusser uses the term Begriff (concept) when discussing images - "Flusser sees photography as 'a picture of concepts' [Bild von Begriffen], which can be said of most images, if one agrees on the essence of concepts [Begriffe]. In the case of photography, they signify 'concepts within a program' [Begriffe in einem Programm]. They are, furthermore, notions about the world [Begriffe der Welt] that the photographer 'encodes in images' [in Bilder verschlüsselt]"” (Belting, 2006, p. 215 apud Guldin, 2007, p. 9). Anyway, for the discussion proposed in this paper, the notion that traditional images are made by human hands seems to be enough, underlining the fact that "Traditional images have real situations as their source; technical images, on the other hand, start out from texts, which in turn have been written in order to break up images through translation" (Guldin, 2007, p. 8).

[6]In a previous text (Loureiro, 2015), a similar claim was made regarding the emergence of descriptive geometry in the history of architectural drawing. The term "descriptive" emphasizes that these drawings were not "created" - they just described the objects as seen from a specific point of view. Given an object and the position of the observer in relation to the object, any draftsman would produce the same drawing, following the same predetermined procedures.

[7]See Loureiro, Bartholo, 2019.; Loureiro, F., Bartholo, R., Mattos, F., Barcelos, F.T, 2020; and Loureiro, F., Bartholo, R., Mattos, F., Sanchez, E., 2020.

[8]The following reflection on Blade Runner draws directly from Prof. Pedro Abreu's lectures at the University of Lisbon in 2006-2007.

[9]"The brain is usually considered the subject of empirical observation in neuroscience. In contrast, the brain as such is not considered the subject of philosophy. For example, there is no well-established 'philosophy of brain' (Northoff, 2004) as distinguished from, for instance, 'philosophy of mind' (Searle, 2004). Unlike the mind, the brain has not yet been intensely scrutinized in epistemology and ontology” (Northoff, 2018, p. 239). 
[10]"Ontology is the study of being, and it deals with the categories of existence and reality" (...) "I carefully distinguish ontology from metaphysics - existence and reality, as understood here, are not mere instances of the more general 'Being as such' as dealt with in metaphysics" (Northoff, 2018, p. 240).

[11]In the early sixteenth century, Albrecht Dürer moved lawsuits against engravers that were copying some of his works, creating similar matrices from his widely available engravings. Emperor Maximillian eventually granted Dürer exclusive control over the reproduction of his engravings, deciding which printers would receive the matrices and how many copies they would be allowed to make. This and other similar cases led to the developed of the "right to copy", or copyright (see Pila, Torremans, 2019, p. 11). 